\title{
YEN LOANS TO MALAYSIA: IMPACT ON FIVE YEAR PLANS FROM 1969 TO 2010
}

\author{
Mohd Ikbal Mohd Huda, Asmadi Hassan, Sulatan Ibrahim
}

\section{Introduction}

In 1988 Malaysia was listed as an Upper Middle Income Country (UMIC). Since then the trend in Japanese Overseas Development Assistant (ODA) to Malaysia gradually changed. With a total Gross Domestic Product (GDP) of USD1.87 billion, with Malaysia being elevated to the UMIC status, it was required to pay aid received within 15-17 years. In comparison to other Southeast Asian nation, Japan began to decrease the amount of ODA to Malaysia. Analysis found that the decrease in allotment of Japanese ODA to Malaysia started between 1986 and 1990 when it only received USD795.24 million compared to Indonesia (USD3.86 billion), Philippines (USD2.4 billion), Thailand (USD1.83billion) and Myanmar (USD808.4 million). Compared to the these countries, the four Malaysian ministries directly involved in the ODA program - Ministry of Foreign Affairs (MOFA), Ministry of Finance (MOF), Ministry of International Trade and Industry and Economic Planning Agency (EPA) supported and understood the reduction of ODA to Malaysia as a consequence of receiving the UMIC status. The amount of yen loan extended to Malaysia also decreased over the years of 1985 to 1990. Yen loan in this period was only 21 million yen which was the smallest amount among all recipient countries in Southeast Asia. The reduction total of aid resulted in Malaysia not applying a yen loan for the first time during the Sixth Malaysia Plan in 1990. This article analyzes the yen loan to Malaysia from 1969 to 2010. Research concluded that the yen loan which amounted to USD1.3 billion over a period of 44 years is significant, especially in eight sectors such as electricity, gas, transportation, social services, mining, agriculture, telecommunications and fisheries. The development of aid orientation is examined in every five-year Malaysian development plans from 1969-2010.

\section{ODA Development in Malaysia ${ }^{1}$}

Japanese investors were and are attracted to Malaysia due to various factors that include political stability and security, responsive government, liberal operating costs, productive workforce, rich raw materials, market opportunities, skills labor, intellectual property protection and harmonious industrial relations has attracted interest of. Aware of the benefits and opportunities offered by Malaysia, Japan adopted the ODA

1 Malaysian development information before independence can be found in the "Draf Pembangunan Malaysia Tahun 1950-1955" at http:/ / www.epu.gov.my/ 
as a foreign policy instrument for stimulating the domestic industry productivity at the micro and macro level. Japanese ODA development in Malaysia should be viewed in the context of the amount of assistance extended to support the five year Malaysia development plans starting from the First Malaysia Plan to the Ninth. It is reasonable to argue that the yen loan assistance since 1969 became the main financial resource in expanding Malaysia`s socio economic sectors.

\section{The First Malaysia Plan1966-1970}

After the establishment of the Organization for Economic Co-operation and Development (OECD) in March 1961, Japan's main focus was to expand economic cooperation at the bilateral and multi-lateral levels to meet the needs of national productivity. Three types ${ }^{2}$ of comprehensive ODA assistance enabled recipient countries to improve their competitiveness as well as reinforce socioeconomic structure. Between 1966 and 1970, Japan channeled JPY692 million to support a five year development plan under the First Malaysia Plan.

This new course of action from japan was because of the implementation of proJapan orientation by Malaysian government managed to attract Japanese ODA to Malaysia. As shown in Table 1, only one public works development project with the Ministry Of Works, Posts and Telecommunication was funded under the first loan yen commitments totaling JPY692 million yen. Not surprisingly, the early stages of this collaboration paved the way towards the implementation of other public works projects till the year 2010. With a total of 16 projects worth JPY119.689 billion, the public works sector became the second most important after the electricity and gas sectors that also received yen loans between 1969 and 2010.

Table1: Yen Loan Projects 1966-1970

\begin{tabular}{|l|l|}
\hline Project & Total (Million Yen) \\
\hline The Public Works Development Project & 692 \\
\hline
\end{tabular}

Source: Modified from http://www2.jica.go.jp/en/yen_loan/

\section{The Second Malaysia Plan 1971-1975}

Prime Minister Abdul Razak's visit to Japan in October 1971 saw the government applying for a Yen loan of JPY36 billion. In the early stages, a total of JPY36 billion was approved, and consequently JPY36 billion was added to support projects under the Second Malaysia Plan. Additional loan packages or omiyage gaikou were channeled during Prime Minister Kakuei Tanaka's visit to Malaysia three years later. With the additional assistance, the entire yen loan commitment to Malaysia amounted to JPY72 billion during the Second Malaysia Plan.

2 Three types of ODA assistance are the yen loan, technical cooperation and grant aid. 
Under the Second Malaysia Plan, joint venture projects between Malaysia and Japan, mainly in the import substitution sector successfully contributed to the Malaysia's economic competitiveness. For instance, the sugar cane plantation as well as sugar refinery factory worth JPY2.997 billion in Perlis was built and targeted as an import substitution project. The plantation managed to produce sugar at low prices in large quantities. About 377,000 tons of sugar was imported by Malaysia in 1970 and the number is equal to $70 \%$ of the demand of refined sugar for the local market. Significantly, the government aimed at developing the sugar refining industry in Perlis as a pioneer industry in order to depend less on imports. The strategy succeeded when annually 62,000 tons of sugar was produced starting from 1971, which in turn managed to reduce $16 \%$ of the amount of sugar imports yearly. ${ }^{3}$

In terms of energy resources, there was an annual increase of 9\% between 1971 and 1975 compared to 1966 and 1970. This was driven by the increase in population and the importance of energy resources $t$ industries. Therefore, the Malaysian government had no choice but to allocate RM161 million for hydro-electric projects. As shown in Table 2, within the five years of the Second Malaysia Plan, a total of three hydroelectric projects namely Temenggor I, II and III worth JPY22.093 billion were built using the yen loans. Although the project was designed by consultants from Canada under the Canadian Assistance programme of 1967, yen loans were used to carry out civil works and purchases of project equipment. The project significantly succeeded in producing large-scale rock fill dam in Malaysia with a capacity of 260MW. Alongside the hydroelectric projects, a total of JPY319 million yen loan was used to finance construction of a bridge in Temerloh as well as other port projects in Johor. The bridge construction in 1973 was designed to overcome floods that hit Temerloh in 1971 and 1972.

Table 2: Yen Loan Projects 1971-1975

\begin{tabular}{|l|c|}
\hline Project & Total (Billion Yen) \\
\hline The Project Of Plantation Refined Sugar Plant In Perlis & 2.997 \\
\hline The Temengor Hydro-Electric Project & 13.300 \\
\hline The Temengor Hydro-Electric Project (II) & 4.091 \\
\hline The Temengor Hydro-Electric Project (III) & 4.702 \\
\hline The Johore Port Construction Project & 0.29 \\
\hline The Temerloh Bridge Project & 0.319 \\
\hline Total & 25.699 \\
\hline
\end{tabular}

Source: Modified from http://www2.jica.go.jp/en/yen_loan/.

\section{The Third Malaysia Plan 1976-1980}

The fourth yen loan package totaling JPY21 billion with an interest rate of $4 \%$ was extended to Malaysia during Takeo Fukuda's visit to Malaysia in August 1977. The fourth yen loan package has two important criterions. First, the assistance of JPY21 billion continued until the 13rd yen loan package. Second, the entire loan was channeled

3 Refer to MOFA, Japan's ODA1993, pp 236. 
through the OECD, as espoused by the agreement between the OECD and the Export Import Bank (EXIM Bank). Malaysia then applied its fifth loan totaling JPY21 billion with 20 years repayment when Prime Minister Hussein Onn visited Japan in August 1977. The sixth yen loan given in October 1979, amounting to JPY21 billion yen followed the same conditions. On the other hand, the seventh yen loan amounting to JPY21 billion was to be repaid in 25 years and this was decided during the fourth year in Plan in November 1980 of the Third Malaysia Plan. All in all, the Japanese ODA worth JPY21 billion was significant in financing 17 projects during the Third Malaysia Plan.

In the period of 1976 to 1980, a number of projects implemented targeted stimulating export promotions. Consequently, Malaysia utilized the yen loan to set up a number of free trade zones (FTZ) and electric power stations in Johor, Pulau Pinang (Prai) and Port Klang. The Prai power station with a capacity of 360MW was funded through the OECD and the EXIM Bank with the third yen loan package. This power plant began supplying energy resources in Pulau Pinang from 1980. The power station managed to increase the industrial productivity of Bayan Lepas FTZ and the Prai FTZ in Pulau Pinang. On the other hand, the power station in Pasir Gudang, Johor with capacity of 240MW which was financed by the OECD through the fourth yen loan began supplying energy in 1982.

It can be argued that 77\% (JPY62.14 billion) of the total yen loans of JPY76.298 billion was used to fund eight projects in Prai, Port Klang, Bintulu, Pasir Gudang, Bersia, Kenering, Kenyir and Tenom Pangi. In addition, the aid was also utilized to purchase four units of gas turbine power stations and to support the expansion of the Prai power station in increasing its capacity to $240 \mathrm{MW}$ compared to the previously capacity of 90MW.

Table 3: Yen Loan Projects 1976-1980

\begin{tabular}{|l|c|}
\hline Project & $\begin{array}{c}\text { Total (Billion } \\
\text { Yen) }\end{array}$ \\
\hline The Third And Fourth Container Cranes Project (Port Kelang) & 1.109 \\
\hline The Prai Power Station & 4.229 \\
\hline The Sabak-Bernam Bridge Project & 0.605 \\
\hline The Crocker Range Crossing Road Project & 7.355 \\
\hline PasirGudang Power Station Project & 7.099 \\
\hline Gas Turbines Project & 3.939 \\
\hline Trengganu Hydro-Electric Project & 2.327 \\
\hline Tenom Pangi Hydro-Electric Project & 0.635 \\
\hline Intra Malaysia Submarine Cable Project & 5.558 \\
\hline Tenom Pangi Hydro Electric Project (II) & 7 \\
\hline Kuala Lumpur (North) - Kampong Awah Transmission Line And Substation \\
Project & 2.055 \\
\hline Bersia Hydro-Electric Project & 3.67 \\
\hline Bintulu Deepwater Port Project & 7.8 \\
\hline Trengganu Hydro-Electric Project (II) & 4.90 \\
\hline Trengganu Hydro-Electric Project(III) & 9.53 \\
\hline Trengganu Hydro-Electric Project (IV) & 2.91 \\
\hline Kenering Hydro-Electric Project & 5.557 \\
\hline Total & 76.298 \\
\hline
\end{tabular}

Source: Modified from http://www2.jica.go.jp/en/yen_loan/ 


\section{The Fourth Malaysia Plan 1981-1985}

With yen loans and capital injections from the Malaysian government, many largescale projects were implemented in the early 1980s by adapting to Japanese style of management and collaborations. For example, the first Malaysia made car project -Proton Saga was produced in collaboration with the car maker Mitsubishi Motors. While, the Perwaja factory was built in collaboration with Japan's largest steel maker, Nippon Steel. A total of USD603.07 million was channeled to support such programs under the Fourth Malaysia Plan. Havinf said that, $80 \%$ of the total yen loan commitments were used to finance a total of 13 projects worth USD482.42 million.

The eighth yen loan package worth JPY21 billion was requested in September 1981. In order to increase capital flows, Prime Minister Dr. Mahathir Mohamad visited Japan in 1983 to apply more yen loans for Malaysia. A year later, this initiative was successful when Japan agreed to extend an additional package worth JPY61 billion to Malaysia. More significantly, this amount is three times higher than any other previous aid packages. The additional package was divided into two parts; first was the ninth yen loan package totalling JPY21 billion and second, a special yen loan amount JPY40 billion. Due to demand for energy resources, the Malaysian government allocated additional funding for the country's energy sector. A total of JPY48.5 billion was channeled into the Klang Port Power Station Project and another JPY12.5 billion was used to finance the Sabah Gas Pipeline Project. The tenth and eleventh yen loan packages worth JPY21 billion were requested in January 1985 and April 1986 respectively. ${ }^{4}$ The special yen loan extended to Malaysia indicates that the Japanese government supported Dr. Mahathir after he declared his Look East Policy (LEP) as a sort of friendship policy between Malaysia and Japan.

During the Fourth Malaysia Plan, the government introduced "market loan" whereby RM1.15 billion was allocated for the promotion of heavy industries. The amount was greater than the amount allocated in the Third Malaysia Plan which was just RM865 million. However, some projects that were funded and implemented failed to achieve their target. One of them was the Sabah Gas Pipeline Project funded under the ninth and tenth yen loan packages worth JPY29.9 billion. The project was initially designed to supply natural gas to steel plants with a capacity of 715,000 tons per year and 660,000 tons to methanol plant in Labuan Island which was facing shortages. Two years after it began its operations, the production of Hot Briquetted Iron (HBI) decreased to $64 \%$ and $90 \%$ to methanol due to inadequate demand for the product. This resulted in the decline of prices of both products as well as produced a deficit of RM205 million in the Sabah Gas Pipeline Project. In other words, Sabah Gas Pipeline Project deficit went up to two-thirds of its operating costs in 1986. Another project that failed during the Fourth Malaysia Plan was the HICOM Steel Plant. However, the HICOM failure was not due to weaknesses in its implementation but because of the postponement of its operation. The factory was supposed to use engines imported from Japan for the

4 Japanese government also channeled special yen loans toIndia and Philippine in 1985 and1986. Special yen loan totalled JPY40 billion to the Philippines to finace a power station project in 1986 during the Aquino administration. While JPY30 billion was channeled to India in 1985 during the Rajiv Gandhi administration. 
use in for Proton cars. However the project was delayed following recommendations in February 1987 from the World Bank. ${ }^{5}$

Failure to implement these projects can be explained by several factors. First, the JPY8.4 billion yen loan extended in April 1986 was not used for the HICOM's project. Second, Malaysia was using the yen loan as a capital injection rather than as a source for obtaining Japanese consultation services. In reality, Malaysia was more dependent on consultation services from the World Bank or the Asian Development Bank (ADB) than Japanese expertise in trying to implement these projects. ${ }^{6}$

The prospects of increasing the country`s energy resources in the Fourth Malaysia Plan was also plagued by several problems due to the over dependency on generating oil resources. It was estimated that crude oil resources in Malaysia remained at 3.5 billion barrels in $198^{7}$ and the source was only expected to last 20 years if Malaysia did not use other alternative energy such as coal and natural gas. This argument is valid since Malaysia's natural gas supply was estimated about 13.8 billion barrels, or four times of crude oil in the 1980s. ${ }^{8}$ To reduce dependency on oil, Dr. Mahathir launched four strategies aimed at diversifying fuel energy sources in Malaysia. ${ }^{9}$ The energy strategy goal in the Fourth Malaysia Plan was to ensure adequate energy supply to support rapid industrial growth and population increase in the 1980s.

A total of eight power station projects were successfully implemented under four fuel strategies and one of them was the Port Klang Power Station Project. ${ }^{10}$ The first phase of the project was implemented on 15 May 1981 under the 7th yen loan package worth JPY14.6 billion. The project was designed to install two unit turbines (2x300MW) with natural gas as a main fuel. While the second, third and fourth phases were implemented between 1981 and 1984. Although the project was designed by the British consulting agency, it was funded by Japanese ODA under the LEP.

Another successful project to replace oil resources was the Batang Ai Power Station Project in Sarawak. Just like the Port Klang Power Station Project, although the project was planned by a consultant agency from Australia, yen loan was used to purchase project equipment, Batang Ai dam civil works and installation of two unit turbines

5 Malaysia graduated from the IBRD from 2009. Refer to http:/ / web.worldbank.org/ and http:/ / data.worldbank.org/

6 Junichi Jamada, Japanese Official Development Assistance in Southeast Asia, ISIS: Kuala Lumpur, 1998, pp 75.

7 Interview with Dr. Mahathir Mohamad at Level 86, Tower 1, KLCC Kuala Lumpur on 9 June 2009.

8 Junichi Jamada, Japanese Official Development Assistance in Southeast Asia, ISIS: Kuala Lumpur, 1998, pg 75 .

The four energy resources are crude oil, crude gas gas, hidro energy and coal.

9 The four energy resources are crude oil, crude gas gas, hidro energy and coal.

10 Port Klang Power Station Project, which is now known as Sultan Salahuddin Abdul Aziz Power Station has been using Japan's consultancy firm, the Electricity Power Development Company International Limited (EPDCI) to draw plans, provide consulting services, project development reports and trial operations. EPDCI project manager, Mr. Takaoka insisted that Japanese firm must be nominated to lead the project due to the LEP which was inspired by Dr. Mahathir. The policy aimed at transforming socio-economic development as well as to implement projects by using Japanese technology, equipment and financial resources. Apart from the Port Klang Power Station and Sabah Gas Pipeline Project, EPDCI also played the same role in Prai Gas Transmission Project. Refer to http:/ / www.jpower.co.jp. 
(2x300MW) to burn coal resources. Significantly, both of the projects successfully reduced dependency on crude oil from $94 \%$ in 1980 to $71 \%$ in 1985.

As shown in table 4, for the period 1981-1985, a total of 13 projects amounting to JPY154.7 billion were financed by yen loan commitment. The power sector received most of the funding with the implementation of eight projects. Meanwhile, the rest of the projects included four in public works and one in manufacturing. ${ }^{11}$

Table 4: Yen Loan Projects 1981-1985

\begin{tabular}{|l|l|}
\hline Project & Total (Billion Yen) \\
\hline Port Klang Power Station Turbo-Alternators Project & 14.6 \\
\hline Port Klang Power Station Boilers Project & 6.4 \\
\hline Railway Transportation Reinforcement Project & 4.6 \\
\hline Batang Ai Hydroelectric Project & 6.1 \\
\hline Asean Urea Project (Malaysia) & 33.6 \\
\hline Batang Ai Hydro-electric Project(Transmission Line) & 3.9 \\
\hline Shunting Locomotives Purchase Project & 1.9 \\
\hline Seremban-Ayer Hitam Toll Expressway Project (Package I) & 4.5 \\
\hline Sabah Gas Grid Project & 12.53 \\
\hline Port Klang Power Station Project (Phase II) & 40 \\
\hline Port Klang Power Station Project (Phase III) & 8.74 \\
\hline Port Klang Power Station Project (Phase IV) & 17.36 \\
\hline Seremban-Ayer Hitam Toll Expressway Project (Package IV) & 0.74 \\
\hline Total & $\mathbf{1 5 4 . 7}$ \\
\hline
\end{tabular}

Source: Modified From http://www2.jica.go.jp/en/yen_loan/.

\section{The Fifth Malaysia Plan 1986-1990}

Declining of tin and palm oil prices in the middle of the 1980s led to the fall of the commodity exports between 1985 and 1986. To deal with price instabilities, the government took initiatives to implement comprehensive strategies especially in developing the industrial sector. In order to attract foreign investors, a new strategy was announced by Dr. Mahathir in New York in September 1986. The new strategy stipulated that foreign investors should be able to retain $100 \%$ equity and the conditions attached were that firms should be able to export $50 \%$ or more of their production and employ at least 350 local employees. In addition, the sale of products in the FTZ factories or Licensed Manufacturing Warehouses (LMW) should be classified as exports. Permits were issued for five foreign workers automatically when project capital exceeded RM2 million. ${ }^{12}$ The new strategy had two significant impacts. First, there was an increase in

11 One special loan channeled for ASEAN Fertilizer in Bintulu totaling JPY48 billion. Malaysia covered $60 \%$ of the equity, Thailand, Philippine and Indonesia 13\% dan Singapore 1\% respectively. The factory started its operation in 1988 and the products were exported to ASEAN member countries.

12 Interview with Dr. Mahathir Mohamadat Level 86, Tower 1, KLCC Kuala Lumpur on 9 June 2009. 
Foreign Direct Investment (FDI) flows into Malaysia beginning 1987 and Japan emerged as the largest investor, followed by the United States and Britain. Second, FDI inflows in the fourth quarter of the Fifth Malaysia Plan recorded the highest amount, reaching RM6.2 billion or equivalent to 6\% of GDP. Consequently, Japanese ODA emerged as a contributor and the biggest FDI into Malaysia for the period of 1986-1990.

To increase investments in to the country, the government used the twelfth yen loan totaling JPY42 billion to fund the Peninsular Gas Development project in June 1986. The project was a government initiative to supply natural gas from East Coast to the West Coast if peninsular Malaysia with over $725 \mathrm{~km}$ length of pipelines. The project funded supplied energy resources to power stations in Pasir Gudang, Port Dickson and Port Klang. Power generated at these stations managed to increase the productivity of the domestic industry as well as exports to Singapore and Thailand through a pipeline extension.

A year after the twelfth yen loan, Takeshita announced a special yen loan stimulus package through the ASEAN-Japan Development Fund (AJDF) ${ }^{13}$ totaling USD2 billion to promote privatization, agriculture and small and medium industries (SMIs) in ASEAN countries. Through the AJDF package, Malaysia received an additional injection of JPY36.7 billion (RM700 million) and all assistance were channeled through the Development Bank, Agricultural Bank and Industrial Bank. The establishment of these three banks as mediator finance institutions (IPI) was a government move designed to provide medium and long-term loan to finance entrepreneur in new industries such as SMEs. Collaboration between these three agencies produced three significant impacts. First, it achieved the target of supporting the export of manufactured goods. Second, it encouraged foreign investors in agricultural resource-based manufacturing. Third, it promoted high value-added industries as well as creating capital-intensive factories. This special yen loan managed by the three banks assisted over 4000 SMEs that operated until 1993.

Since listed as UMIC nation in 1988, the nature of ODA to Malaysia changed gradually, specifically starting from the thirteenth yen loan package. However, Dr. Mahathir took an initiative to visit Tokyo and apply for more yen loans in October 1988. He proposed two points for consideration: the following yen loan should be amortized in the Malaysia ringgit. Second, the exchange rate was to be fixed once the loan agreement was concluded. However, Takeshita was not agreeable as the proposal would cause a change in OECD's operational guidelines and pose difficulties for ministries involved in Japanese ODA programs such as the Japan International Cooperation Agency (JICA), Japan Bank for International Cooperation (JBIC), MOFA, MOF and MITI. ${ }^{14}$ However, Takeshita agreed to channel the loan at effective transaction rate, known as "Loan Sector" and "Development Loan" to Malaysia in July $1989 .{ }^{15}$ Significantly, the 13rd yen loan package given in February 1990 totaled JPY62.9 billion and this became the largest ODA amount provided to Malaysia. Overall, as shown in table 5, a total of JPY158.402 billion yen loan was channeled to finance 14 projects between 1986 and 1990 .

\footnotetext{
3 http://www.aseansec.org.

14 http://www.jica.go.jp/malaysia

15 Ibid.,
} 
Table 5: Yen Loan Projects 1986-90

\begin{tabular}{|l|c|}
\hline Project & Total (Billion Yen) \\
\hline Asean Urea Project & 4.797 \\
\hline Diesel Electric Locomotive Purchase Project & 2.3 \\
\hline Optical Fiber Cable System Project & 0.6 \\
\hline Highway Toll System Project & 1.683 \\
\hline Diesel Electric Locomotives Purchase Project(Phase II) & 4.618 \\
\hline EngkililiSibu Transmission Line Construction Project & 4.357 \\
\hline Peninsular Gas Utilization Project (Stage 2) & 42 \\
\hline AJDF Category B (Bank Pembangnan Malaysia Berhad) & 10.442 \\
\hline AJDF Category B (Bank Pertanian Malaysia) & 10.442 \\
\hline AJDF Category B (Bank Industri Malaysia Berhad) & 5.89 \\
\hline AJDF Category B (Malaysian Industrial Development Finance) & 10.013 \\
\hline Rural Development (Poverty Eradication) Project (II) & 32.498 \\
\hline Regional Development (Poverty Eradication) Project & 9.318 \\
\hline Malayan Railway Improvement Project & 19.444 \\
\hline Total & 158.402 \\
\hline
\end{tabular}

Source: Modified from http://www2.jica.go.jp/en/yen_loan/.

\section{The Sixth Malaysia Plan 1991-1995}

With the end of the New Economic Policy $(\mathrm{NEP})^{16}$, another new government policy named National Development Policy (NDP) was introduced. This new policy aimed at macro economic development particularly to strengthen Malaysia`s productivity and competitiveness at the global level. In order to achieve the target, the government required domestic and international support for this development process. Japan continued channeling aid to Malaysia. For the first two years of the Sixth Malaysia Plan, fourteenth and fifteenth yen loan total JPY62.9 billion and JPY53.9 respectively were provided to finance 11 projects in various sectors (see Table 6). However, due to the lengthy process in channeling aid which took time, Dr. Mahathir decided to stop applying for yen loans in August 1993.

Some of the projects undertaken in the Sixth Malaysia Plan successfully reduced the dependency on oil to produce energy. One of the worst tragedies in Malaysian history, a 24 hours electricity interruption in 1992 not only resulted in blackouts all over the country, but also disrupted socioeconomic productivity. ${ }^{17}$ This tragedy and the realization of the significant need of energy resources to smooth productivity flow in domestic industries forced the government to allocate RM1.6 billion to upgrade and finance power station projects. ${ }^{18}$ Partly, the yen loan was also utilized to finance the third phase of the Port Klang Power Station ${ }^{19}$ which installed two turbines fuel mixture (2x500MW) which functioned to burn natural gas and coal.

16 Utusan Online, 24 October 2008.

17 Interview with Dr. Mahathir Mohamad at Level 86, Tower 1, KLCC Kuala Lumpur on 9 June 2009.

18 Ibid.,

19 An insterst of 3.0\% interest rate was imposed for the Port Klang project and the period of repayment was 25 years. The Tenaga Nasional Berhad, assisted by Economy Planning Unit 
In addition, fuel projects mainly from coal resource successfully stabilized electricity supply in peninsular Malaysia for the period between 1992 and 1995. In the Sixth Malaysia Plan, electricity supplied by Port Klang Power Stations covered about $6 \%$ to $7 \%$ of total usage. Research found that the project contributed electricity to peninsula Malaysia 6\% of electricity supply annually starting from 2001 to 2010. To sustain foreign investments, adequate electricity supply was significant, especially to Japanese investors to ensure productivity in 20 sectors in 1358 factories all over Malaysia. ${ }^{20}$

Table 6: Yen Loan Projects 1991-1995

\begin{tabular}{|l|c|}
\hline Project & Total(Billion Yen) \\
\hline Higher Education Loan Fund Project & 5.493 \\
\hline Rural Development (Poverty Eradication) Project (2) & 10.949 \\
\hline Small And Medium Scale Industry Promotion Program (Smipp) & 4.66 \\
\hline Small And Medium Scale Industry Promotion Program (Smipp) & 4.66 \\
\hline Small And Medium Scale Industry Promotion Program (Smipp) & 4.66 \\
\hline Port Klang Power Station Project (Phase 3) & 31.966 \\
\hline Rehabilitation Of The TenomPangi Hydropower Project & 0.543 \\
\hline Projek Wilayah Persekutuan Labuan & 3.7 \\
\hline Hospital UniversitiKebangsaan Malaysia (HUKM) & 10.215 \\
\hline Port Klang Power Station Project (Phase 3 - Stage 2) & 39.955 \\
\hline Kuala Lumpur International Airport Project & 61.518 \\
\hline Total & 178.319 \\
\hline
\end{tabular}

Source: Modified from http://www2.jica.go.jp/en/yen_loan/.

\section{The Seventh Malaysia Plan 1996-2000}

A very significant scenario occurred in the Seventh Malaysia Plan when the largest ODA was distributed in one fiscal year amounting to JPY119.247 billion, for three environmental conservation projects on 31 March 2000. These projects were Port Dickson (Tuanku Jaafar) Power Station Rehabilitation Project II, Kenyir Hydroelectric Power Plant Project II and 13 sewage treatment plants project which focused on improving the hygiene standard and minimize any negative impacts of electricity consumption on the environment.

Analysis found that all three projects achieved the target of environmental conservation. Until middle of 2012, a total of 13 sewage treatment ${ }^{21}$ plants worth JPY 48.5 billion (RM1.89 billion) were successfully implemented with the yen loan commitment and the project 2.8 million people in urban and high density areas. Japanese equipment

to implement the project. The project aimed at fulfilling the electricity demand in Peninsular Malaysia as well as to provide stable electricity in factories near Klang Port.

20 Statistic shows that until 2011, 1412 Japanese firms in various industries in 20 sectors in Malaysia. Out of this, 54 are in Sabah, Sarawak and Labuan. Please refer http://www.jetro. go.jp/malaysia/

21 The list of 13 waste treatment plants can be obtained at http:/ / www.bernama.com. 
with the ability to process polluted waste was used in the treatment process. ${ }^{22}$ Other projects include nine sewage treatment plants, four plants of sludge treatment facilities and two non-physical projects, administrative projects and consultancy services. The rest of the projects were follow ups of earlier projects such as the Pahang-Selangor Raw Water Transfer Project, HELPII, SMI and LEP. Table 7 shows the total amount of yen loan projects from the 1996 to 2000.

Table 7: Yen Loan Projects 1996-2000

\begin{tabular}{|l|c|}
\hline Project & Total (Bilion Yen) \\
\hline Kenyir Hydroelectric Power Plant Project II & 16.994 \\
\hline Port Dickson (Tuanku Jaafar) Power Station Rehabilitation Project II & 53.764 \\
\hline Sewerage Treatment Plant Project & 48.489 \\
\hline Engineering Services For Pahang-Selangor Raw Water Transfer Project & 1.093 \\
\hline Higher Education Loan Fund Project II & 5.285 \\
\hline Universiti Malaysia Sarawak Development Project & 18.549 \\
\hline Beris Dam Project & 9.737 \\
\hline Port Dickson (Tuanku Jaafar) Power Station Rehabilitation Project & 49.087 \\
\hline Fund For Small And Medium Scale Industries & 16.296 \\
\hline Look East Policy & 14.026 \\
\hline Total & 233.320 \\
\hline
\end{tabular}

Source: Modified from http://www2.jica.go.jp/en/yen_loan/.

\section{The Eighth Malaysia Plan 2001-2005}

When Dr. Mahathir stepped down, Abdullah Ahmad Badawi became the Prime Minister and his administration lasted six years (2003 and 2009). Malaysia-Japan bilateral relationship that had prevailed for 46 years was further strengthened with frequent visits to Japan by Abdullah. ${ }^{23}$ From the period of 2001 to 2005, Japan provided USD400.77 million to Malaysia. 41.7\% of the assistance or USD167.14 million was used to finance the Pahang-Selangor Raw Water Transfer Project II. Apart from energy resources, one of the crucial components in generating the productivity of 856 Japanese factories in Peninsular Malaysia was providing sufficient water supply. Past water crises, particularly the one that took place between 1997 and 1998 had a negative impact on the water resource management system in Malaysia.

Malaysia and Japan were committed to ensure that the crisis would not recur. As shown in table 9, the yen loan was used to finance Pahang-Selangor Raw Water Transfer Project II in the Eighth Malaysia Plan. The project involved two main phases, namely the supply of raw water from Pahang to Selangor via underground tunnels between Karak in Pahang and Hulu Langat in Selangor as well as establishing a water treatment

22 http://www.bernama.com.

23 As the Malaysian Prime Minister between October 2003 and December 2006, Abdullah Badawi visited Japan four times. In Japanese perception, even though it colonised it previously, Malaysia began to be recognised as a trading partner and is seen as a model of development. Refer to BeritaHarian, 10 December 2003 and Utusan Malaysia, 29 May 2006. 
plant in Hulu Langat. Until the middle of 2012, Langat River water treatment plant could only produce up to 478 million liters per day. Low water reserve margin had the potential to disrupt water supply, especially in dry season which caused shortage of raw water in Selangor. The building of the Pahang-Selangor Raw Water Transfer Project II as well as Langat water treatment plant was a rational step towards avoiding another water crisis. It is predicted that the project is capable of treating raw water up to 1.89 billion liters per day, which will be channeled to Selangor, KualaLumpur and Putrajaya till 2025.

In addition, the Eighth Malaysia Plan also involved security elements mainly in the Malacca Straits. Although Malaysia is fortunate in that it is relatively free from unwanted tragedies, the ODA contribution is significant in order to ensure security of the Malacca Straits. As an international trade oriented country, Malaysia is not spared from the instability that could affect its trade partners. ${ }^{24}$ Apart from being a major route for fuel tankers such as petroleum and natural gas, a dramatic increase in sea traffic through the strait began to occur when China began to increase its productivity for global trade. Recognizing the importance of the Straits of Malacca as the most critical shipping lane in international trade as well as a potential target for piracy (Table 8), Japan adopted the ODA as an instrument to work with littoral countries like Malaysia to deal with any potential threat.

Researchers argue that the security in the Malacca Straits is important for Japanese industry since approximately $80 \%$ of crude oil is transported through the Malacca straits. ${ }^{25}$ This clearly demonstrates the importance of Malacca Straits as a major reason for contribution of Japanese ODA to Malaysia. Analysis found that cooperation between "JICA Maritime Guard and Rescue Project"26 with the Malaysian Maritime Enforcement Agency is significant to ensure the security of Malacca Straits. ${ }^{27}$ To deal with the various forms of external threat that could undermine national interests, Japan has provided 10 units of speed boat, 40 high-tech binoculars, 40 night binoculars and 60 digital mobile radios to the Malaysian Maritime Enforcement Agency.

Table 8: Piracy Attack in Malacca Straits 2000-2005

\begin{tabular}{|c|c|}
\hline Year & Case \\
\hline 2000 & 75 \\
\hline 2001 & 17 \\
\hline 2002 & 16 \\
\hline 2003 & 28 \\
\hline 2004 & 38 \\
\hline 2005 & 12 \\
\hline Total & $\mathbf{1 8 6}$ \\
\hline
\end{tabular}

Source : "Annual Report on Piracy and Armed Robbery against Ships",

1 January-31 December 2005, http:/ / www.icc-ccs.org. United Kingdom: ICC International Bureau, pg. 5

${ }^{24}$ Refer to Najib Razak's speech during the MAJECA-JAMECA meeting at Seri Kembangan, Kuala Lumpur on 1 September 2004.

25 Utusan Malaysia, 2 September 2004.

26 Refer to http://www.my.emb-japan.go.jp/English/ODA/maritime_seminar.html.

27 Utusan Malaysia, 2 September 2004. 
Table 9: Yen Loan Projects 2001-2005

\begin{tabular}{|l|c|}
\hline Project & Total (Billion Yen) \\
\hline Pahang-Selangor Raw Water Transfer Project & 82.04 \\
\hline
\end{tabular}

Source: Modified from http://www2.jica.go.jp/en/yen_loan/.

\section{The Ninth Malaysia Plan 2006-2010}

For the Ninth Malaysia Plan, Japan provided USD577.12 million. 76.4\% (USD441.35 million) of the funding financed the HELP Project III (Table10). The continuity of the education project proved that Japan is committed to materialize its third promise made by Kishi in 1957, particularly to offer scholarships and to recruit more students from Malaysia to study in Japan. Significantly, the project produced a total of 424 bumiputera engineers and scientists currently serving in various Malaysian industrial and public sectors. ${ }^{28}$ The project also indicates that Malaysia's future success depends on the quality and expertise of its human capital as an asset to drive Malaysia Vision 2020.

Table 10: Yen Loan Projects 2006-2010

\begin{tabular}{|l|c|}
\hline Project & Total (Bilion Yen) \\
\hline Higher Education Loan Fund ProjectIII & 7.644 \\
\hline Total & 7.644 \\
\hline
\end{tabular}

Source: Modified from http://www2.jica.go.jp/en/yen_loan/.

In addition, analysis found that Japanese ODA commitments also established new economic cooperation projects in the automotive and biotechnology industries. In order to create a more competitive industry, Malaysia and Japan signed the Japan-Malaysia Economic Partnership Agreement (JMEPA) in 2006. The new economic cooperation had a very significant impact in the automotive industry with the establishment of the Malaysia-Japan Automotive Industries Cooperation (MAJAICO). ${ }^{29}$ The institution offers advanced training to Malaysian workers and has led to the production of quality automotive components in Proton and Perodua. The establishment of the automobile institution is significant and is in line with the national objectives of developing a car component industry by small and medium enterprises to meet domestic and international needs.

Meanwhile, in order to diversify energy resources in Malaysia, the two countries have established a more comprehensive collaboration in the biotechnology industry. Two factors have contributed to this phenomenon. First, Malaysia has experience and expertise in oil palm research. Second, the imbalance of the global situation has caused the destabilization of world petrol and diesel prices. ${ }^{30}$ As such,

The biotech industry can be a foundation of new cooperation between Malaysia and Japan. Not necessarily just focus on biodiesel, but also to other areas such as the food, biofuels, medicines, cosmetics and herbs. I believe that biotechnology will be one of successful

${ }_{28}$ For futher information about the HELP project, please refer to www.jadypm.edu.my.

29 Refer to http:/ / www.adtecsa.gov.my.

30 Ibid. 
areas of cooperation between the two countries. Research on Malaysian palm oil should be focused to produce a fuel source that is now too dependent on petrol and diesel."131 "Japan will cooperate with us. If there is anything that can be leveraged to us, then we will work together. This partnership will not be a problem because palm oil research in Malaysia is at high level and Malaysia have everything and extensive experience in the commodity research. However, it should be tailored to the goal of making palm oil as highest quality bio-oil and Japan will cooperate with us in achieving this goal.

\section{Conclusion}

Taking into consideration the economic strength, business-friendly policies, political stability and national security, a responsive government, liberal investment policies, tax incentives, conducive investment climate, low operating costs, market opportunities, labor, raw materials, intellectual property protection, productive workforce, harmonious industrial relations, advance infrastructure and robust business environment, for many years, Japanese investors have been attracted to Malaysia. Overall, this article concludes that the yen loan extended to Malaysia, from the First to Ninth Malaysia Plan amounting to USD1, 242.45 million has helped the process of modernizing Malaysia. It can be reasonably argued that 74 projects funded by the yen loans, in six sectors, namely electricity and gas, ports, transportation, telecommunications, social services, mining, manufacturing and agriculture have helped develop Malaysia.

Japan`s focus on six keys sectors has given positive impact, especially to strengthen the socio-economic structure of Malaysia. The success of projects implemented such as HELP, power station project, Pahang-Selangor Raw Water Transfer Project, high-tech sewage treatment plant project, civil work project etc., benefited roughly 28.85 million Malaysians. An estimation of 1412 of Japanese enterprises in 20 different sectors paved the way for providing employment opportunities to Malaysians. This argument is supported by Takeshi Aoki in his study of Japanese investments in Malaysia. Aoki concluded that the success of industrial joint ventures is due to the effectiveness of Japanese firms in Malaysia. Transfer facilities and factories in 20 sectors in Malaysia have become the center piece of the success. Further, Kioshi Kojima in his book entitled "Japan and a New World Economic Order" argues that the good business environment is the main factor for promoting Japanese investments in any country.

Overall, Japanese ODA has given a dominant impact on the Malaysia socioeconomic performance; particularly the opening of Japanese factories in the 20 sectors has provided employment opportunities to Malaysians. For example, according to statistics published by PROTON in 2012, Malaysia-Japan joint ventures have provided a total of 12,000 jobs opportunities to Malaysians.

31 Ibid. 